\title{
Local Government in the South Pacific Islands
}

\author{
Commonwealth Journal of Local Governance \\ Issue 1: May 2008 \\ http://epress.lib.uts.edu.au/ojs/index.php/cjlg
}

\section{Graham Hassall \& Feue Tipu ${ }^{1}$ \\ University of the South Pacific}

\section{Introduction}

In this paper we seek to answer some basic questions about the condition of local government in the Pacific. Firstly, we examine what is meant by 'local government' in the various islands and for that matter how Pacific Island states have perceived and accepted local government institutions in practice; second, we ask basic questions about existing legal and constitutional recognition and powers; and third, we provide initial findings on current per capita expenditure and local government financial viability in a number of Pacific cities and towns. We also make some observations on current moves towards local government reform.

We ask these questions for a number of pressing reasons. Firstly, although Pacific societies have governed themselves locally for thousands of years through traditional institutions, procedures and value systems, the term 'local government' has come to be associated in recent decades with the governing of the few towns and the even fewer 'cities' in the small island developing states of the Pacific region. Local government, in other words, implies not just institutions that are newly created, and that are in urban as distinct from rural (or village) areas, but which are in so many ways foreign to Pacific cultures and lifestyles. There is therefore much conceptual work

\footnotetext{
1 The authors acknowledge the research assistance by Raijieli Bulatale and Amrita Nand. Other informants include Ms Cherol Ala, Deputy Director Dept of Local Authorities, Ministry of Internal Affairs, Vanuatu; Ms Benateta Betero, Assistant Secretary, Local Government Division, Ministry of Internal and Social Affairs, Kiribati; Iete Avanitele, Director of Rural Development, Ministry of Home Affairs and Rural Development, Tuvalu; Pita Vuki, Deputy Secretary, Prime Minister's Office, Tonga; Maulolo Tavita Amosa, Department of Local Government, Samoa; Terry Parker, CLGF Pacific Project; and Azmat Khan, Secretary/Treasurer, Fiji Local Government Association, Mr. Pioni Willie, National Statistics Office of Vanuatu, and Professor Ted Wolfers, University of Wollongong. Additional data for tables has been sourced from http://www.paclii.org (Pacific Islands Legal Information Institute) and http://www.state.gov/misc/list/index.htm (the US Department of State), including in some cases local government departments.
} 
to do to articulate the notion of the 'Pacific city' and the 'Pacific town', and to articulate the most desirable relations between towns and their hinterlands. Many Pacific towns have emerged on the foundations of administrative centres associated with colonial authority, and are yet to adequately address questions about how they assist their inhabitants lead satisfying lifestyles and reach their highest developmental aspirations whether these are economic, social, or even artistic.

Secondly, we feel - and the data identified in the course of researching this paper has confirmed for us this view - that local government bodies in the Pacific region are critically under-resourced. Given the constant influx of migrants from outer islands to the urban and peri-urban areas, and their tendency to enter the informal rather than formal economy and to be nonrate-paying 'free-loaders' on public facilities, there is little prospect that many town and city councils in the Pacific region will be able to significantly improve their capacities for service delivery or for infrastructural development in the short to medium term. This is exacerbated by the current inter-governmental arrangements by which national governments make minimal transfers to local governments to facilitate service delivery. We agree with Storey and others who have noted that: "Pacific Island towns and cities are becoming places of acute poverty and growing inequality", and: "Institutions are failing to cope with demands placed on them" (Storey, 2006).

Thirdly, local government in Pacific Island nations has received inadequate scholarly attention despite the urgency of the issues confronting this level of government. This is notwithstanding the considerable efforts that have been and are being made to make a difference through legal and policy reform, and to some extent through experimentation with styles and degrees of devolution. When decolonization occurred in the Pacific Islands (from the 1960s to 1980s) the newly formed independent states found it necessary to refocus attention on decentralization and the strengthening of local government (Larmour and Qalo in Wolfers, 1985). Public sector reforms in the 1980s and 1990s that aimed at increasing efficiency, productivity and accountability, and that were part of the global phenomenon of 'reinventing government', included efforts to promote and strengthen local government. Fiscal crises, frustration with central government services, and political instability spreading across the Pacific provided the impetus for governance reform.

Globally, reforms aimed at accomplishing the Millennium Development Goals have significance at local level. ${ }^{2}$ (The United Nations Economic and Social Commission for Asia and the Pacific - UNESCAP) has an ongoing interest in urban development in Pacific Island countries, although research efforts have been uneven in their coverage. One past project on 'Local

\footnotetext{
2 For the Pacific region see www.mdgasiapacific.org and www.undp.org.fj See also UNCDF, 2007 \& Kiyagi-Nsubuga, 2007 which explore the relationship between local government performance and MDG attainment.
} 
Government in Asia and the Pacific', for example, included Fiji as the sole case study from the Pacific Islands. ${ }^{3}$ A major symposium on local government in the Pacific region convened in Suva in 2004 by the Commonwealth Secretariat and Commonwealth Local Government Forum (CLGF) was more comprehensive (CommSec, 2005).

Within the Commonwealth, the 'Commonwealth Principles on Good Practices for Local Democracy and Good Governance' (commonly referred to as 'The Aberdeen Agenda') provides a set of standards for the promotion of healthy democracy and good governance. It is also a basis for research directions for future work relating to local government (CLGF, 2005). However, whilst this paper draws on and supplements information provided in the excellent 2007 Commonwealth Local Government Handbook, and in other works on the Pacific, it has nonetheless been prompted by the lack of published basic data on local government in the Pacific Island states - a paucity of research about the region that can be contrasted with the expanding field of local government internationally. The difficulties that we faced in obtaining basic data for this paper, such as the current populations and budgets of Pacific towns, are indicative of the poor state of information generally available about the sector.

Better baseline information is essential for subsequent research into the actual operation of local government in the Pacific region. Therefore this paper is very much a 'work in progress'.

\section{What is local government in Pacific Island states?}

The term 'local government' refers to the tier or tiers of government below that of national government. There are twelve independent small island states in the Pacific region and a similar number of dependent states and territories. $^{4}$ A majority of these states are in fact archipelagos, and in a number of cases, local government equates with 'government of the island'. In such instances, local government can refer to government of village (or rural) communities, or to a mixture of village and urban communities. In Kiribati and Tuvalu, some islands are classified as '100\% urban', and yet others as ' $100 \%$ rural'. Urban councils are referred to as town councils and the rural councils as island councils. Both have the same legal standing but their individual responsibilities vary according to those granted to them at the time of establishment. In the case of Tuvalu, 53\% of the population is rural with the other $47 \%$ comprising the population of the capital island of Funafuti which is the only urban council in the country. To date we have

\footnotetext{
$3<$ http://www.unescap.org/huset/lgstudy/index.htm> accessed 30 October 2007.

4 Independent states: Federated States of Micronesia, Fiji, Kiribati, Marshall Islands, Nauru, Palau, Papua New Guinea, Samoa, Solomon Islands, Tonga, Tuvalu and Vanuatu Dependant states and territories: American Samoa (US), Commonwealth of the Mariana Islands (US), Cook Islands (NZ), Guam (US), New Caledonia (France), Niue (NZ), Norfolk Island (Australia), Papua / West Papua (Indonesia), Pitcairn Island (UK), Rapa Nui (Chile), Tahiti - French Polynesia (France), Tokelau (New Zealand), Wallis \& Futuna (France).
} 
not found a comprehensive tabulation of the numbers of cities, towns and villages in the Pacific Island countries. The following chart (Table 1) is therefore an initial enumeration.

Table 1: Numbers of villages, towns, cities, and other local level authorities in nine Pacific Island countries

\begin{tabular}{|c|c|c|c|c|c|c|c|c|c|c|}
\hline & $\overline{\bar{z}}$ & 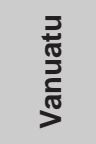 & 들 옹 & 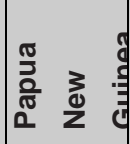 & 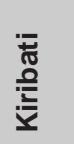 & 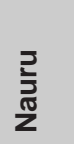 & 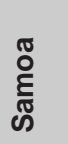 & 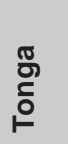 & 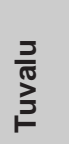 & Total \\
\hline $\begin{array}{l}\text { Provinces/ } \\
\text { Divisions }\end{array}$ & 14 & 6 & 9 & 20 & $?$ & $?$ & $?$ & 5 & & 49 \\
\hline Districts & & & & 89 & 6 & 14 & 11 & 24 & 0 & 144 \\
\hline Cities & 2 & 0 & 1 & 3 & 0 & 0 & 0 & 0 & 0 & 6 \\
\hline Towns & 10 & 2 & 1 & 50 & 3 & 0 & 0 & 0 & 1 & 66 \\
\hline Villages & 1,175 & 2,149 & ? & ? & $?$ & $?$ & 247 & 167 & 9 & ${ }^{*} \dagger$ \\
\hline $\begin{array}{l}\text { Local-level } \\
\text { Gov'ts }\end{array}$ & & 8 & 11 & $299+$ & 23 & & 247 & & 8 & \\
\hline
\end{tabular}

Source: Government of Tonga, Statistics Dept (1997); Tonga population census, 1996. Nuku'alofa, Tonga, Statistics Dept.; Khan, A. (2007). Local Government in Fiji. Suva, Fiji Local Government Association.

$\uparrow$ Given that there is no figures provided for 4 countries this row has not been tabulated so as to not give a wrong impression of the number of villages.

\$ The 299 local-level governments in Papua New Guinea are comprised of 26 urban municipalities and 273 councils. Local level governments are themselves made up of wards. In PNG's case, there are 6,003 wards. Wards are made up of villages and hamlets

This table suggests the existence of six cities in the nine Pacific Island countries under investigation (Suva, Lautoka, Honiara, Port Moresby, Lae, and Mt Hagen), and some 66 towns. The 'capital' in some states appears not to have the formal designation 'city'. Villages number in the thousands but no reliable figure has yet been tabulated. In fact, traditional habitation in some parts of Papua New Guinea consists of hamlets rather than villages, and the emphasis on the 'village' is more a result of administrative convenience during the colonial era than a reflection of their importance to local communities.

We have suggested that, broadly speaking, the term 'local government' refers to the tier or tiers of government below that of national government, and that local government arrangements for the Pacific countries often blend traditional (or customary) governance with democratic government. Whereas the distinction between 'rural' and 'urban' environments is generally understood, (see Spoehr, 1963; Harre, 1973), clear legal definitions of the 'city', 'town' and 'village' do not necessarily exist in the legislation of Pacific Island countries. What is clear, however, is that references to a village in the majority of cases imply a native settlement that has been recognized as such. In the cases of a city and town, it is usually the case for some kind of legal declaration to be made under the relevant law. The town of Apia in Samoa is an exception to the rule; there is no town authority or municipality and Apia town comprises a number of 
traditional villages that are governed under the Village Fono Act of 1990. Issues affecting the urban area as a whole are generally matters for central government agencies, but there is no overall authority.

The impacts of urbanization are becoming a major concern for most of the Pacific Island states. Obviously, the growth of towns is matched by a consequent depopulation of rural areas. A significant emerging feature of Pacific towns and cities and including villages, is the proliferation of new settlements that fall outside the legal or traditional boundaries of these centres - what have come to be called 'peri-urban' areas (Storey, 2006). In the cases of towns and cities, there is a rapidly growing challenge of squatter settlements.

The case of Fiji illustrates the escalating challenge facing Pacific Island states. ${ }^{5}$ In this country of just two cities, ten towns, and 14 provinces, recent statistics indicate the Suva-Nausori corridor has the highest number of squatter settlements ( 72 with 8,687 households), followed by Nadi (19 settlements totalling 1208 households), Labasa and Lautoka (15 settlements each), and Ra and Sigatoka (10 settlements each). The situation in Fiji has been aggravated by the demise of the sugar industry, with many farmers migrating to towns and cities to seek employment.

The movement of villagers to settlements just beyond town boundaries raises the issue of how and whether town boundaries should be expanded in recognition of this growth in populations requiring services. ${ }^{6}$ Some $83 \%$ of the nation's land is owned by indigenous Fijians while $9 \%$ is state land and $8 \%$ is freehold. Because urban development has already consumed most state and freehold land, future urban growth will require access to adjoining land owned communally by indigenous Fijian clans. This poses major challenges for effective urban governance and community relations.

\section{Constitutional and legal frameworks}

Five of the island states under review (Papua New Guinea, Solomon Islands, Vanuatu, Kiribati, and the Marshall Islands) have specific constitutional provisions for local government whilst others (Fiji, Samoa, Tuvalu, Cook Islands, Nauru and Tonga) do not. This is not to suggest, however, that local government has no substantive presence in the actual conduct of constitutional systems. In nearly all the island countries, there is constitutional and/or statutory recognition of traditional chiefly leadership, with provisions for the inclusion of chiefs in local government or the

\footnotetext{
5 The pressures on Fiji's cities and towns is attracting increasing media attention: in 2007 Fiji's "squalid shanty towns" drew the attention of Time magazine: Callinan, R. (2007). Wrong Side of Paradise. Time: 27-31. The cover story for Fiji Islands Business in October 2007 read "Urban Explosion: Gripping and choking our main urban centres".

6 The Urban Fijian Programme Unit within the Ministry of Fijian Affairs has, as part of its remit, to address the issues surrounding the inclusion of Fijian villages within the boundary of a municipality.
} 
establishment of a 'council of chiefs'. Local government arrangements often blend traditional (or customary) governance with democratic governance.

\section{Fiji Islands}

Fiji has established municipal councils in urban areas, but has retained a separate administrative system for Fijian villages. Whereas municipal councils come under the ambit of the Local Government Act (Cap. 125), Provincial Councils that cover rural areas are established by virtue of the Fijian Affairs Act (Cap. 120). As such two sets of local government bodies are governed by different government ministries. The country's 14 provinces are divided into smaller administrative units, commencing with the village (koro). At the head of the village is the turaga-ni-koro, elected or appointed by the villagers. Several koro make up a (tikina) or district, and several tikina make up a yasana or province. Each province is headed by a Roko Tui.

The Fijian Affairs Board, constituted under the Fijian Affairs Act (Cap 120), governs all matters concerning the administration of indigenous Fijian affairs, including Fijian custom services. The Board refers certain matters to the Great Council of Chiefs, constituted by the President under the same Act. The former Qarase government adopted a 20-year development plan for the Enhancement of Participation of Indigenous Fijians and Rotumans in the Socio-economic Development of Fiji Islands, although the status of this program is unclear since the military takeover in December 2006.

In Fiji's case, neither the 1990 or the 1997 constitution made specific provision for local government. The 1996 Constitution Review Commission considered that the constitution should not expressly recognize local government or guarantee local government autonomy. It did, however, recommend that:

\footnotetext{
The Government should commission a broad and comprehensive review of all local government arrangements in Fiji to be carried out by an independent and broadly representative body. This review should, in the light of modern needs, re-examine the organization, functions and powers of all the existing local government bodies provided by law. The terms of reference should include a review of the operation of those bodies that exist without a statutory basis. The reviewing body, among things, should be required to inquire into appropriate democratic systems of local government for rural areas (Reeves et al, 1996).
}

This recommendation is important on many counts. Firstly, the Commission recognized the complexity of existing arrangements in which parallel local government systems operate side by side. Second, it noted the urgent need to review the current situation with a view to seizing the 
opportunities being presented by globalization and the associated advancement in information technology.

Table 2: Local Government Populations in Fiji

\begin{tabular}{|l|r|r|r|r|}
\hline \multicolumn{1}{|c|}{ Local Government body } & \multicolumn{1}{c|}{$\begin{array}{c}\text { Area } \\
\mathbf{( k m 2 )}\end{array}$} & $\begin{array}{c}\text { Population } \\
\text { (town) }\end{array}$ & $\begin{array}{r}\text { Population } \\
\text { (peri-urban) }\end{array}$ & \multicolumn{1}{c|}{$\begin{array}{c}\text { Total urban } \\
\text { population }\end{array}$} \\
\hline Suva & 327 & 6,775 & 8,960 & 15,735 \\
\hline Lami & 2,048 & 75,225 & 10,953 & 86,178 \\
\hline Nadi & 680 & 10,474 & 9,749 & 20,223 \\
\hline Nasinu & 577 & 11,871 & 30,841 & 42,712 \\
\hline Nausori & 4,500 & 75,719 & 11,051 & 86,770 \\
\hline Lautoka & 167 & 24,630 & 22,181 & 46,811 \\
\hline Levuka & 1,607 & 44,143 & 8,599 & 52,742 \\
\hline Sigatoka & 67 & 1,143 & 3,147 & 4,290 \\
\hline Tavua & 127 & 1,542 & 7,904 & 9,446 \\
\hline Labasa & 100 & 1,076 & 1,373 & 2,449 \\
\hline Savusavu & 360 & 7,550 & 19,900 & 27,450 \\
\hline
\end{tabular}

Source: Provisional Results, Population and Housing Census www.statsfiji.gov.fj

Some 32 national laws, spread across a range of government ministries, affect the work of local government in Fiji. The Ministry of Local Government and Urban Development oversees the role and functions of the municipal councils as stipulated in the Local Government Act 1985 (Cap 125). Three other key Acts were passed in 1978: the Town Planning Act [Cap. 139], the Fijian Affairs Act [Cap. 120], and the Subdivision of Land Act [Cap. 140]. The Public Enterprise Act 1996, which sought to transform some public enterprises into limited companies, and to convert them partially or totally into private organizations, also had some impact on the functions of local government. Electricity supply in towns and fire services, for example, were amalgamated into national services.

Although local councils have a degree of autonomy, they are required by law to submit for approval their annual budget estimates; monthly financial statements/activity reports; annual financial reports; resolutions to increase fees or charges, or create new fees or charges; and loan applications that exceed $5 \%$ of the recurrent estimated gross revenue of the council.

Notwithstanding the fact that no full assessment of the performance of Fijian town councils has been undertaken, several have been suspended in recent years due to poor performance. In January 2008 the current Minister for Local Government addressed the issue of improving the quality of governance in an address to the Fiji Local Government Association: 


\begin{abstract}
In Fiji I am saddened to say that our municipal councils have made little or no progress since the system of elected local government councils were inducted in accordance with the prevailing laws of this country. ... Over the years there has been no meaningful review of the Local Government Act and relevant regulations to ensure that it met the demands of a changing population and developing towns and cities...As such we have in place local government legislation which is in need of serious and expedient review and I shall be liaising with the Attorney General's Chambers for an urgent review of the Local Government Act... However in recent times, municipal councils have become known more for complaints against them rather than being complimented for the service that they provide or rather ought to provide (Fiji Local Government Association, 2008).
\end{abstract}

Whereas on the one hand the national government may have good reason to chastise town councils in Fiji for the quality of their performance, we must also ask whether the councils are sufficiently resourced financially and in terms of capacity, to undertake the responsibilities required of them. In 2007 the Fiji Local Government Association issued a 'White Paper' outlining the challenges facing local government in the coming period, among which are an "urgent need to revise and update the legal framework", more "self-upgrading capabilities" by councils, and greater collaboration between government agencies and civil society in order to avoid traditional "top-down" approaches to policy formulation (Khan, 2007). An assessment of per capita expenditure, provided below, suggests that Fijian town councils have minimal resources at their disposal to achieve these objectives, and that exploration of options for expansion of revenue sources is one crucial area for further investigation.

\title{
Vanuatu
}

In the case of Vanuatu, the country's independence constitution provides for local government and decentralization, the division of the country into Local Government Regions, and for each region to be administered by a council on which shall be representatives of custom chiefs. Of the country's 83 islands, 14 have a land surface of more than 100 square kilometres. Its two towns - Port Vila (the capital) situated on Efate, and Luganville, on the northern island of Espiritu Santo - are administered by municipal councils, while rural communities are served by provincial councils. The constitution also provides for the establishment of a National Council of Chiefs (the 'Malvatumauri') to oversee matters relating to custom and tradition. Local government was shaped by Acts passed in 1980 - the year that national independence was attained. These include the District Administration Act [Cap 106] and the Municipalities Act [Cap. 126]. Subsequent related legislation includes the Physical Planning Act [Cap.193] of 1987; the Decentralisation Act [Cap. 127] of 1994, which affords the Minister with powers to select chiefs from amongst persons nominated by representative bodies to be members of local government councils. 
The national government consolidated the provincial council system through the Decentralisation and Local Government Regions Act 1994, which amalgamated single-island authorities and shifted executive powers from the presidents of the provincial councils to secretary generals who are public officers. The names of the six provincial councils derive from the initial letters of their constituent islands, as indicated in Table 3. Each of these six councils has a central administration plus local areas headed by an area secretary who resides in the villages and reports to the council's secretary general (CEO). Provincial councils have the discretion to establish committees as they see fit - none are required by law - but the composition of committees must reflect the political proportionality of the council as a whole. Many establish finance committees and physical planning committees.

Vanuatu provincial councils and the Department of Local Authorities are under the Ministry of Internal Affairs. The Minister responsible for local government ensures that provincial councils operate in accordance with government policy. The Minister has responsibility for the Decentralisation Act; Municipalities Act; Physical Planning Act and Foreshore Development Act, and also has the authority to suspend a council and appoint commissioners as its replacement. As in Fiji, local government authorities in Vanuatu have been suspended on a number of occasions; Port Vila Council in 2005, and Luganville Council in 2006 amidst claims of misappropriation of public funds. Also in 2006, the Sanma provincial council was dissolved on the basis of continued absence of councillors from meetings and allegations of mismanagement and corruption (Jowitt, 2007).

Table 3: Local Government Populations in Vanuatu

\begin{tabular}{|l|r|r|}
\hline Province or Municipality & \multicolumn{1}{l|}{$\begin{array}{l}\text { Area } \\
\text { (km2) }\end{array}$} & Population \\
\hline Torba (Torres islands, Banks islands) & 865 & 7,774 \\
\hline Sanma (Santo, Malo) & 4,136 & 25,446 \\
\hline Penama (Pentecost, Ambae, Maewo - in French: Pénama) & 1,204 & 26,503 \\
\hline Malampa (Malakula, Ambrym, Paama) & 2,772 & 32,738 \\
\hline Shefa (Shepherds group, Efate - in French: Shéfa) & 1,505 & 24,841 \\
\hline Tafea (Tanna, Aniwa, Futuna, Erromango, Aneityum - in French: Taféa) & 1,628 & 28,915 \\
\hline Port Vila Municipality & - & 29,729 \\
\hline Luganville Municipality & - & 10,734 \\
\hline
\end{tabular}

Source: Population data for Vanuatu was kindly provided by Cherol Ala, Deputy Director in the Dept. of Local Authorities, Ministry of Internal Affairs, Vanuatu. 


\section{Papua New Guinea}

Papua New Guinea has the most elaborate and hierarchical local government arrangement, with provincial, district and local-level governments (LLGs) as well as wards for communities and villages. There are 20 provincial governments comprising 89 district councils. Under the district councils are 299 local-level governments (26 urban and 273 rural), which in turn comprise 6,003 wards. These wards are made up of thousands of hamlets and villages. Although the rank of 'chief' exists in many Papua New Guinea societies, this is one constitutional and legal system in the region that does not grant them recognition. Table 4, which shows the distribution of local government bodies across Papua New Guinea's 20 provinces, indicates that only five have more than one urban area and that in Papua New Guinea local government may be predominantly focused on rural communities and concerns, rather than urban.

Table 4: Distribution of Local Governments and Population in Papua New Guinea

\begin{tabular}{|c|c|c|c|c|}
\hline Province & $\begin{array}{c}\text { Number of } \\
\text { Urban } \\
\text { LLGs }\end{array}$ & $\begin{array}{c}\text { Number of } \\
\text { Rural } \\
\text { LLGs }\end{array}$ & $\begin{array}{c}\text { Total } \\
\text { Population }\end{array}$ & $\%$ Urban \\
\hline Bougainville & 3 & & 154,000 & 15.8 \\
\hline Central & & 13 & 148,195 & 4.7 \\
\hline Chimbu & 1 & 18 & 183,849 & 3.9 \\
\hline Eastern Highlands & 3 & 8 & 300,648 & 8.5 \\
\hline East New Britain & 1 & 17 & 185,459 & 11.8 \\
\hline East Sepik & 1 & 25 & 254,371 & 10.4 \\
\hline Enga & 1 & 13 & 235,561 & 1.7 \\
\hline Gulf & 1 & 9 & 68,737 & 10.5 \\
\hline Madang & 1 & 15 & 253,195 & 14.2 \\
\hline Manus & 1 & 11 & 32,840 & 17.6 \\
\hline Milne Bay & 1 & 15 & 158,780 & 6.9 \\
\hline Morobe & 3 & 31 & 380,117 & 26.4 \\
\hline National Capital & 1 & & 195,570 & 100 \\
\hline New Ireland & 1 & 8 & 86,999 & 9.4 \\
\hline Oro & 1 & 7 & 96,491 & 14.5 \\
\hline Sandaun & 1 & 16 & 139,917 & 8.3 \\
\hline $\begin{array}{l}\text { Southern } \\
\text { Highlands }\end{array}$ & 3 & 27 & 317,437 & 2.6 \\
\hline Western & 3 & 11 & 110,420 & 18.3 \\
\hline $\begin{array}{l}\text { Western } \\
\text { Highlands }\end{array}$ & 1 & 14 & 336,178 & 6.2 \\
\hline West New Britain & 1 & 10 & 130,170 & 14.8 \\
\hline
\end{tabular}

Source: Commonwealth Local Government Forum (2007). Commonwealth Local Government Handbook 2007. NB: This data is currently being updated 
The independence constitution of 1975 provided for local government, and the national government made extensive efforts throughout the 1980s and 1990s to improve the delivery of basic services in education and health, as well as infrastructure and economically sustainable development at the local level. By the mid-1990s, however, an assessment that provincial governments and local governments were not operating efficiently resulted in an extensive overhaul of the system. The resulting Provincial Government Reform Act of 1995 significantly altered the provincial government system such that members of parliament who represented a province automatically became governor of the province while retaining their parliamentary seats. Other key legislation includes the Organic Law on Provincial Governments and Local-Level Governments 1995 and the Local-Level Governments Administration Act 1997 (see Filer, 2004). To date, unfortunately, there is little evidence suggesting that the reforms have made a significant difference to the performance of local government authorities. In the case of Port Moresby, formally designated the National Capital District, abuse of office and political intrigue were endemic, at least around the time of the 1995 changes. As reported by Gelu:

The Port Moresby City Council became a bed for corruption by politicians to satisfy their own personal interests. As a result the City Council has collapsed to a stage where it cannot carryout its responsibilities such as collecting the rubbish, cleaning the streets, cutting the grass, providing markets and so on... Two Commissions of Inquiry revealed massive fraud in the financial accounts of the City Council but to date no one has been prosecuted. The reports contained numerous cases of politicians paying money to non-existent contractors and the misuse of properties belonging to the city council Gelu, 2003).

\section{Solomon Islands}

In the Solomon Islands, the same period of the 1980s and 1990s saw a shift towards more decentralized democracy. As in the case of Papua New Guinea, the 1978 Solomon Islands independence constitution provides for sub-national government at the provincial level. There are currently nine provinces (Central, Choiseul, Guadalcanal, Isabel, Makira-Ulawa, Malaita, Rennell and Bellona, Temotu, and Western). The Local Government Act 1985 replaced an Act dating from 1964 but did not produce the expected results of providing efficient delivery of basic services to rural and outlying areas. ${ }^{7}$ There is currently in process an exercise to overhaul the Solomon Islands constitution, and to more fully entrench provincial authorities. The perceived failings of the 'modern' system of government have brought calls for the promotion of the roles of chiefs in government (Ghai, 1990). White notes that the local view of government is that of "a distant presence with uncertain relevance for everyday life" (White, 2003).

\footnotetext{
7 Other principal legislation includes the 1982 Provincial Government Act [Cap 118]; the 1995 Mamara-Tasivarongo-Mavo Development Agreement Act [Cap 145]; the 1996 [Revised Edition] Town and Country Planning Act [Cap 154] 1996; the Provincial and Local Government Act 1997; the Local Government Ordinance, and the Honiara City Council Act 1999.
} 
The Ministry of Home Affairs currently has responsibility for oversight of local government in Honiara, including compliance with the law and giving consent to policies, rates, charges, loans and financial matters. The Minister is empowered by the Honiara City Council Act to suspend the council. Dissolution of the Honiara City Council took place in 1990 and again in 2004.

Table 5: Local Government Populations in Solomon Islands

\begin{tabular}{|l|r|r|}
\hline \multicolumn{1}{c|}{ Local Government } & \multicolumn{1}{c|}{$\begin{array}{c}\text { Area } \\
\text { (km2) }\end{array}$} & \multicolumn{1}{c|}{ Population } \\
\hline \multicolumn{1}{c|}{ Honiara City } & 22 & 69,189 \\
\hline Central Province & 615 & 24,491 \\
\hline Choiseul Province & 3,837 & 31,259 \\
\hline Guadacanal Province (excluding Honiara) & 5,336 & 84,438 \\
\hline Isabel Province & 4,136 & 23,638 \\
\hline Makiva Province & 3,188 & 50,026 \\
\hline Malaita Province & 4,225 & 140,569 \\
\hline Rennell \& Bellona Province & 671 & 4,409 \\
\hline Temotu Province & 895 & 23,800 \\
\hline Western Province (including Noro Town) & 5,475 & 81,852 \\
\hline
\end{tabular}

Source: Solomon Islands Household Income and Expenditure Survey, National Report 2005/06, p20

\section{Micronesia}

In Kiribati, local government is enshrined in the 1979 constitution but effectively governed by the Local Government Act, first passed in 1984 and revised in 2006. Over the past decades there has been gradual devolution of powers with the aim of engaging and empowering people at the local level to take charge of their own development. Changes include election of the chief councillor by all the island population, but not from amongst newly elected councillors. ${ }^{8}$ In reality however, functions are shared between central and local government and central government retains oversight responsibility. For example, the powers of the Minister set out in the Local Government Ordinance 1966 and the Local Government Act 2006 provide for oversight of local government policy, assisting local councils in drafting by-laws, undertaking internal audits, and compiling final accounts for the Auditor General's scrutiny. However, in recent years there has only been one case in which the minister intervened and suspended a council due to corruption/abuse of office.

\footnotetext{
8 The change is interesting because in one respect it testifies to the faith and acceptance by the people of Kiribati of the manner and process through which their President (Beretitenti) is elected at the national level.
} 
Table 6: Local Government Populations in Kiribati

\begin{tabular}{|c|c|c|}
\hline Local Government body & Area & $\begin{array}{c}\text { Population } \\
\text { (2005 Census) }\end{array}$ \\
\hline Makin & 7.89 & 2385 \\
\hline Butaritari & 13.49 & 3280 \\
\hline Marakei & 14.13 & 2741 \\
\hline Abaiang & 17.48 & 5502 \\
\hline Tarawa - North (rural) & 15.25 & 5678 \\
\hline Tarawa - South (urban) & 10.10 & 27808 \\
\hline Betio Town (urban) & 1.50 & 12507 \\
\hline Maiana & 16.72 & 1908 \\
\hline Abemama & 27.37 & 3404 \\
\hline Kuria & 15.48 & 1082 \\
\hline Aranuka & 11.61 & 1158 \\
\hline Nonouti & 19.85 & 3179 \\
\hline Tabiteua - North & 25.78 & 3600 \\
\hline Tabiteuea - South & 11.85 & 1298 \\
\hline Beru & 17.65 & 2169 \\
\hline Nikunau & 19.08 & 1912 \\
\hline Onotoa & 15.62 & 1644 \\
\hline Tamana & 4.73 & 875 \\
\hline Arorae & 9.48 & 1256 \\
\hline Banaba & 6.29 & 301 \\
\hline Teeraina & 9.55 & 1155 \\
\hline Tabuaeran & 33.73 & 2539 \\
\hline Kiritimati (urban) & 388.39 & 5115 \\
\hline TOTAL & 713.03 & 92496 \\
\hline
\end{tabular}

Source: Data provided by the Local Government Division of Kiribati.

In the case of the republic of Nauru (one of the smallest sovereign states anywhere in the world), the fortunes of local government have been as volatile as those of government at national level. ${ }^{9}$ In 1992 the national government dissolved the Nauru Local Government Council and replaced it with the Nauru Island Council (NIC). The former council had made poor investment choices and was accused of gross mismanagement. Acting as a local government and providing public services, NIC was elected from the same constituencies as the parliament, except that 7 of the 8 constituencies returned 1 member, and the constituency of Ubenide returned 2 members, making 9 in all. Several members of parliament also served as councillors. NIC was itself dissolved in 1999 and all assets and liabilities became vested

\footnotetext{
9 In the 1990s corruption and mismanagement brought the country near to bankruptcy; in 2008 the country remains without a banking system.
} 
in the national government. Presumably, given Nauru's current fiscal crisis and small size, fewer levels of government will continued to be regarded as the most appropriate course.

\section{Polynesia}

Local government systems in Samoa and Tonga are both based on traditional and customary practices and norms. In the case of Tonga, 23 Districts and 167 Villages are spread across the nation's three main island groups, and their governance is conducted by and through the office of the Governors of Ha'apai and Vava'u, together with a small network of elected and district officials. ${ }^{10}$

For Samoa, the village councils which administer local affairs are composed of Matais, who are the heads of extended families. For administrative purposes, Samoa is divided into 11 districts which are made up of around 250 villages. ${ }^{11}$ Local government is administered in accordance with the Village Fono Act 1990 and the Internal Affairs Act 1993. Some $29 \%$ of the population lives in urban areas, and the average population of each fono is 1,300 . A Matai is designated by each family to represent it in the village council, which administers local affairs. The Minister for Women, Community and Social Development is responsible for local government matters and for enacting legislation and providing leadership in the sphere. The minister's powers are derived from the Internal Affairs Act 1995. ${ }^{12}$ On occasion the minister has suspended pulenu'u (village 'mayors' - representatives who liaise with the central government) for not performing well. The Samoan government has in recent years placed particular emphasis on economic revitalization. This has focused on agricultural sector and micro-enterprises and the village economy is at the centre of this policy.

In Tuvalu, the creation of the Gilbert and Ellice Islands protectorate in 1892 (covering what are now the separate independent states of Kiribati and Tuvalu) saw the establishment of local administration by elected island councils. A 1966 Local Government Ordinance established for the 8 inhabited islands provided the framework for a policy aimed at financing local services at the island level. Island councils are now administered in accordance with the Falekapule Act of 1997. ${ }^{13}$ This Act creates elected

\footnotetext{
10 Legislation regarding local government in Tonga comprises the District and Town Officers Act Cap 43] 1930, the Town Regulations Act [Cap 44] 1903, and the Fonos Act (Cap 50) of 1924 (note also 1991: Fonos (Amendment) Act).

${ }_{11}$ There are variations in estimates of the total number of villages in Samoa. The Britannica On-line gives a figure of 360 or more villages; CLGF (Pacific Project) has estimated that a more realistic figure for Samoa would be around 250.

12 Note also the 1997 Internal Affairs Amendment Act.

13 Additional power devolved from Central government to Island Councils through the Tupe Fakanaa A Falekaupiule Act 1999 (Local Government Trust Fund Act). Funafuti [the main island] Town Council (1) and the other 7 island councils each consist of 6 elected members and provide a limited range of local services
} 
local governments (called Kaupule) to undertake a range of functions in consultation with the Falekaupule (traditional island meetings), and to participate fully and actively in national developmental programmes and projects. The Act effectively extends statutory recognition of the Falekaupule as a primary social institution and the sovereign power in the islands by vesting upon them the right to oversee local affairs with the Kaupule as their executive arm.

Table 7: Local Government Populations in Tuvalu

\begin{tabular}{|l|c|c|}
\hline \multicolumn{1}{|c|}{ Island } & Area (sq km) & Population \\
\hline Funafuti & 2.79 & 4,492 \\
\hline Nanumea & 3.87 & 664 \\
\hline Nanumaga & 2.78 & 589 \\
\hline Niutao & 2.53 & 663 \\
\hline Nui & 2.83 & 548 \\
\hline Vaitupu & 5.60 & 1,571 \\
\hline Nukufetua & 2.99 & 586 \\
\hline Nukulaelae & 1.82 & 393 \\
\hline Niulakita & 0.42 & 35 \\
\hline
\end{tabular}

Source: Data obtained from the Kaupula Financial Year Budget for 2007

In the Cook Islands, the Outer Island Local Government Act of 1987 consolidated and amended the law relating to establishment and conduct of local government in the islands other than Rarotonga. It was subsequently amended by the Outer Island Local Government Amendment Act of $1993 .{ }^{14}$ Local government councils in Rarotonga were constituted by virtue of the Rarotonga Local Government Act of 1997, but were dissolved early in 2008 due to their poor delivery of services. As indicated in the following table, some of the Cook Islands outer island communities are extremely small, and this characteristic has significant impact on the scale of operation of all local government entities. Due to limited resources and lack of any economies of scale, local government in such micro-states will inevitably remain circumscribed for some time to come.

\footnotetext{
14 Other relevant provisions are found in the Palmerston Island Local Government 1993, as well as the 1966 Cook Islands Ordinance Amendment; 1973-4: Local Government Amendment; and 1990 Outer Islands Local Government Amendment.
} 
Table 8: Local Government Populations in Cook Islands

\begin{tabular}{|l|c|c|}
\hline \multicolumn{1}{|c|}{ Island } & Area (sq km) & Population \\
\hline Te-au-o-tonga* & 67.1 & 5,445 \\
\hline Pauikura* $^{*}$ & & 4,343 \\
\hline Takitumu* $^{*}$ & & 4,365 \\
\hline Aitutaki & 18.3 & 2,194 \\
\hline Mangaia & 51.8 & 654 \\
\hline Atiu & 26.9 & 572 \\
\hline Mauke & 18.4 & 393 \\
\hline Mitiaro & 22.3 & 219 \\
\hline Manihiki & 5.4 & 351 \\
\hline Penrhyn & 9.8 & 251 \\
\hline Rakahanga & 4.1 & 141 \\
\hline Pukapuka & 1.3 & 507 \\
\hline Nassau & 1.3 & 71 \\
\hline Palmerston & 2.1 & 63 \\
\hline
\end{tabular}

Source: Cook Islands "Cook Islands Census 2006."

*Now abolished

\section{FINANCING LOCAL GOVERNMENT}

Financial viability is crucial to local government effectiveness. In nearly all cases, island councils in the states of the South Pacific are besieged by lack of resources, whether human or financial. Whilst some countries may have the capacity and scope to overcome their financial woes, others clearly need a strong dose of resourcefulness and creativity in terms of revenue generation as well as their expenditure patterns.

In Fiji, central government provides supervisory support to municipal councils, but there is no formal policy of revenue-sharing. ${ }^{15}$ The total budget for local government in Fiji in 2007 was FJD 37.62 million. Under the new Urban Policy Action Plan the government provides matching grants on a 50-50 basis (Challenge Fund) for infrastructure projects that benefit the poor. The following table indicates that per capita expenditure by urban local governments in Fiji ranges widely. It should be noted that Nasinu, an urban area adjacent to Suva and with about the same population, has per capita expenditure of just $\$ 42$. When the presence in these urban areas of large numbers of squatters is taken into account, the levels of per capita expenditure are lower still.

\footnotetext{
15 Municipal councils are required to transfer to central government $5 \%$ of revenues collected under S16 of the Business License Act 1978 (Cap 204). This was derived from General Rates on property, Market Fees, Council Properties, Business Licenses, Bus Station Fees, Taxi Base/Carrier Fees, Rental Properties, Garbage Fees, and Recreation Facilities.
} 
Table 9: Local Government Expenditure in Fiji

\begin{tabular}{|l|c|c|c|c|}
\hline \multicolumn{1}{|c|}{ City or Town } & $\begin{array}{c}\text { Area } \\
\text { (km2) }\end{array}$ & $\begin{array}{c}\text { Population } \\
\text { (Town) 2007 }\end{array}$ & $\begin{array}{c}\text { Annual Budget } \\
\text { (F\$) }\end{array}$ & $\begin{array}{c}\text { Local Govt } \\
\text { Expenditure } \\
\text { F\$ per capita }\end{array}$ \\
\hline Ba & 327 & 6,775 & $2,000,000$ & 295 \\
\hline Suva (City) & 2,048 & 75,225 & $18,000,000$ & 239 \\
\hline Lami & 680 & 10,474 & $1,300,000$ & 124 \\
\hline Nadi (largest urban & 577 & 11,871 & $3,000,000$ & 253 \\
\hline Nasinu & & & & 42 \\
\hline center) & 4,500 & 75,719 & $3,200,000$ & 81 \\
\hline Lausori & 167 & 24,630 & $2,000,000$ & 113 \\
\hline Levuka & 1,607 & 44,143 & $5,000,000$ & 149 \\
\hline Sigatoka & 67 & 1,143 & 170,000 & 486 \\
\hline Tavua & 127 & 1,542 & 750,000 & 279 \\
\hline Labasa & 100 & 1,076 & 300,000 & $\mathrm{n} / \mathrm{a}$ \\
\hline Savusavu & 360 & 7,550 & $\mathrm{n} / \mathrm{a}$ & $\mathrm{n} / \mathrm{a}$ \\
\hline
\end{tabular}

Source: The Secretary, Fiji Local Government Association, Suva [22/10/2008]

In Vanuatu substantial transfer payments are made from central to local government, but these are subject to annual budgetary provisions and do not follow a set formula. The grants fall into two categories: $70 \%$ for budgetary support (administrative expenses) and 30\% for small capital projects. Central government pays the salaries and allowances of secretaries-general and accountants of provincial councils. Other sources of revenue for local government in Vanuatu are similar to those in Fiji (eg business licenses; vehicle charges; waterfront development and physical planning fees). While local government can alter the fees charged for various services, it has no authority over the level of taxes. A review of recent per capita expenditure at local government level suggests that despite the transfers from central government, expenditure per citizen remains low. 
Table 10: Local Government Expenditure in Vanuatu

\begin{tabular}{|l|c|c|c|c|}
\hline \multicolumn{1}{|c|}{ Province/Municipality } & $\begin{array}{c}\text { Area } \\
\text { (km2) }\end{array}$ & Population & $\begin{array}{c}\text { Annual Budget } \\
\text { (Vatu) }\end{array}$ & $\begin{array}{c}\text { Local Govt } \\
\text { Expenditure } \\
\text { Vatu per capita }\end{array}$ \\
\hline Torba & 865 & 7,774 & $40,198,600$ & 5,170 \\
\hline Sanma & 4,136 & 25,446 & $54,552,550$ & 2,144 \\
\hline Penama & 1,204 & 26,503 & $43,307,840$ & 1,634 \\
\hline Malampa & 2,772 & 32,738 & $54,296,500$ & 1,659 \\
\hline Shefa & 1,505 & 24,841 & $76,540,694$ & 3,081 \\
\hline Tafea & 1,628 & 28,915 & $42,498,000$ & 1,470 \\
\hline Port Vila Municipality & - & 29,729 & $287,570,000$ & 9,673 \\
\hline Luganville Municipality & - & 10,734 & $73,472,000$ & 6,843 \\
\hline
\end{tabular}

Source: Commonwealth Local Government Association (2007). "Commonwealth Local Government Handbook."

Table 11: Local Government Expenditure in Tuvalu

\begin{tabular}{|l|c|c|c|c|}
\hline \multicolumn{1}{|c|}{ Island } & $\begin{array}{c}\text { Area (sq } \\
\text { km) }\end{array}$ & Population & $\begin{array}{c}\text { Annual } \\
\text { Budget 2007 } \\
\text { (AUD) }\end{array}$ & $\begin{array}{c}\text { Local Govt } \\
\text { Expenditure } \\
\text { AUD per } \\
\text { capita }\end{array}$ \\
\hline Funafuti & 2.79 & 4,492 & 438,881 & 97.70 \\
\hline Nanumea & 3.87 & 664 & 383,496 & 577.55 \\
\hline Nanumaga & 2.78 & 589 & 238,809 & 405.45 \\
\hline Niutao & 2.53 & 663 & 244,469 & 368.73 \\
\hline Nui & 2.83 & 548 & 243,666 & 444.65 \\
\hline Vaitupu & 5.60 & 1,571 & 272,104 & 173.20 \\
\hline Nukufetua & 2.99 & 586 & 237,744 & 405.71 \\
\hline Nukulaelae & 1.82 & 393 & 190,484 & 484.69 \\
\hline Niulakita & 0.42 & 35 & 22,604 & 645.83 \\
\hline
\end{tabular}

Source: Data obtained from the Kaupula Financial Year Budget for 2007

A number of Pacific states have established 'trust funds' to generate income through investment. In the case of Tuvalu, where the Tuvalu Trust Fund was first established in 1987 (Finn, 2002) an additional Falekaupule Trust Fund was established in 1999 with the specific purpose of assisting financial development on outer islands. The fund, established under the Falekaupule Act, is an agreement between the national and local governments (Kaupule) who are the beneficiaries of the fund, as distributions are made in proportion to the original contribution of each of the eight participating islands Graham, 2005). Per capita expenditure by local government in Tuvalu is higher all around than is the case in Kiribati, the closest neighbouring state with a somewhat comparable economic environment. While the reasons for this require additional investigation, it 
could be surmised that Tuvalu's trust fund is contributing significantly to the wellbeing of communities at local level.

Table 12: Local Government Expenditure per capita in Kiribati

\begin{tabular}{|c|c|c|c|c|}
\hline & Area & $\begin{array}{c}\text { Population } \\
\text { (2005 Census) }\end{array}$ & $\begin{array}{c}\text { Annual Budget } \\
\text { A\$ (2007) }\end{array}$ & $\begin{array}{c}\text { Local Govt } \\
\text { Expenditure per } \\
\text { capita A\$ }\end{array}$ \\
\hline Makin & 7.89 & 2385 & 103,408 & 43.36 \\
\hline Butaritari & 13.49 & 3280 & 158,934 & 48.46 \\
\hline Marakei & 14.13 & 2741 & 130,521 & 47.62 \\
\hline Abaiang & 17.48 & 5502 & 200,661 & 36.47 \\
\hline Tarawa - North (rural) & 15.25 & 5678 & 213,312 & 37.57 \\
\hline Tarawa - South (urban) & 10.10 & 27808 & 701,718 & 25.23 \\
\hline Betio Town (urban) & 1.50 & 12507 & 533,017 & 42.61 \\
\hline Maiana & 16.72 & 1908 & 144,028 & 75.49 \\
\hline Abemama & 27.37 & 3404 & 230,273 & 67.65 \\
\hline Kuria & 15.48 & 1082 & 70,700 & 65.34 \\
\hline Aranuka & 11.61 & 1158 & 159,096 & 137.39 \\
\hline Nonouti & 19.85 & 3179 & 193,865 & 60.98 \\
\hline Tabiteua - North & 25.78 & 3600 & 187,087 & 51.97 \\
\hline Tabiteuea - South & 11.85 & 1298 & 113,782 & 87.66 \\
\hline Beru & 17.65 & 2169 & 131,225 & 60.50 \\
\hline Nikunau & 19.08 & 1912 & 111,473 & 58.30 \\
\hline Onotoa & 15.62 & 1644 & 132,022 & 80.31 \\
\hline Tamana & 4.73 & 875 & 77,743 & 88.85 \\
\hline Arorae & 9.48 & 1256 & 116,430 & 92.70 \\
\hline Banaba & 6.29 & 301 & 85,715 & 284.77 \\
\hline Teeraina & 9.55 & 1155 & 116,811 & 101.14 \\
\hline Tabuaeran & 33.73 & 2539 & 240,686 & 94.80 \\
\hline Kiritimati (urban) & 388.39 & 5115 & 118,543 & 23.18 \\
\hline Total & 713.03 & 92496 & & \\
\hline
\end{tabular}

Source: Local Government Division of Kiribati

In Kiribati there is no set policy regarding revenue-sharing between central and local government: transfer payments are made to support balanced individual authority budgets. Certain percentages are reserved for specific activities such as the maintenance of roads and causeways, offices, school buildings, hospitals, and housing for government-seconded staff. Central government pays the full salary of seconded staff and contributes substantially towards the salaries and wages of council staff. Assistance is also given for office stationery and provision of ferries between main islands and islets that cannot be accessed by road. The minister retains the power to approve or reject local authority budgets. 
Local government authorities in Papua New Guinea raise revenue from taxes, fees and charges, and property rates. Local governments may levy charges on community services, public entertainment, general trading licenses, and domestic animals and corporations. The Organic Law on Provincial Governments and Local-Level Governments provides a formula for the sharing of revenue between levels of government, which takes into account administration grants (unconditional), staffing grants, development grants, and town/urban services grants. Local salaries are paid by central government. In each province, local governments feed into the Joint District Planning and Budget Priorities Committee, which in turn reports to the Joint Provincial Planning and Budget Priorities Committee.

In the Solomon Islands, substantial transfer payments are made from central government to Honiara City and the provinces to cover running costs and capital expenditure. The Minister's approval is required for variations in tax. The City and provinces are responsible for collecting and raising taxes, while central government is responsible for salaries of staff in schools, health clinics and technical staff seconded to work in local government. The Minister's approval is required for variations in tax. In Honiara, total revenue for the City Council in 2007 was SID \$17,096,000. This was drawn from taxes and fees on property, individual residents (a Head tax), business fees, gaming (under the 1961 Gaming and Lotteries Act [Cap 139], vehicles, liquor, and services provided.

\section{LOCAL GOVERNMENT REFORM}

In the face of the considerable challenges facing local government in the Pacific Islands, some encouraging steps toward local government reform have been initiated. At regional level, the Pacific Urban Agenda was agreed by member countries in 2003, and revised in 2007. A few specific reform efforts are mentioned here as examples of what is happening at national level.

A review of local government has taken place in Fiji, but there remain areas for further examination. It is expected that a number of Acts will be amended in addition to the principal Local Government Act 1985 (Cap 125). ${ }^{16}$ The Fiji Local Government Association (FLGA) is working with the Ministry of Local Government, the Commonwealth Local Government Forum and other agencies on a 'Good Urban Governance' program, in addition to the Urban Policy Action Plan and the Urban Growth Management Action Plan. The Training and Productivity Authority of Fiji (TPAF) provides ongoing training for councils, to which local authorities contribute a levy equivalent to $1 \%$ of their payroll.

\footnotetext{
16 These include the Public Health Act 1985; Town Planning Act 1978; Sub-divisional Land Act 1978; Land Transport Authority Act 1998; Shop (Regulation of Hours Employment) Act; and the Litter Decree 1991
} 
Also in Fiji, FLGA and individual councils are pursuing technical partnerships with local governments in New Zealand, Australia and the USA as a means of strengthening their capacity and improving performance. FLGA itself is developing a partnership with Local Government New Zealand (LGNZ - the national association) as part of the regional capacity-building programme for local governments in the Pacific, funded by the New Zealand and Australian agencies for international development (NZAID and AusAID) and managed by CLGF. The CLGF Pacific Project is supporting a number of other partnerships for Fiji town councils. In addition, FLGA is hoping to promote further sister city relationships with the USA, through Sister Cities International (SCI), to include programmes on technology, environment, healthcare and public safety issues.

The CLGF is also managing a NZAID-funded capacity building and good governance project for Honiara City Council. There are also moves to update parts of the Honiara City Council Act. In Vanuatu a Decentralization Review Commission is to report and it is expected that this will influence reforms to be introduced over the medium-long term.

\section{CONCLUSIONS}

Local government in the South Pacific is a complex blend of modern democratic principles and government systems with traditional institutions and practices, and often extremely small-scale. Its current status reflects both a history of robust traditional governance in all of the island states under investigation, and also the failure of central government to provide or support effective service delivery at the local level. In a way, one could argue that local government in the South Pacific are still in a transitional stage to more effective and autonomous entities, but this argument should be set against the backdrop of the social and economic realities of the island countries.

This paper has noted the lack of study of local government in the Pacific Islands, and the need to remedy this situation in light of the immense challenges being faced in the island nations of the region. On the basis of the data presented above, we highlight the following key issues:

* Local-level governments in the Pacific Island countries may be constituted as a city, a town, a village, or an island. While approximately half of the Pacific Islands population (excluding Papua New Guinea) live in urban areas, the number of local government entities for cities and towns is much smaller than the number in rural areas (villages and island councils). The latter are usually very small and few can be expected to develop into effective, modern authorities, whereas they often play an important role linked to traditional 
governance. Large populations now live in squatter settlements which, jurisdictionally speaking, may place them outside the scope of a recognized local government authority. That is, they live in peri-urban areas beyond city or town limits, and outside the authority of their traditional village leadership or contemporary village council.

* Current levels of funding for local government, particularly when expressed in per capita terms, are not sufficient if Pacific cities and towns are to provide adequate levels of service and infrastructure development in the short-medium term. For example, expenditure in the Fiji national capital, Suva, is just FJD239 per citizen per year. Similar low per capita expenditure is found in Kiribati, where just AUD42 per annum is spent in the main urban centre, Betio.

* Urban planning has taken place on a small and sporadic scale in the Pacific states, but has not resulted in adequate preparation for current levels of urban growth complexity of intergovernmental relations, or citizens' aspirations. There are considerable constraints on land available for urban development, and the expansion of city and town boundaries, although much needed in some instances, is difficult to achieve due to socio-political constraints associated with customary ownership of adjoining lands. Moreover, there has been little assessment of the quality of life in urban areas. CLGF is pursuing an Urban Governance Indicators project that should advance knowledge in this area.

* The quality of inter-governmental relations has not been adequately researched. At a time when the small states require increased transparency, efficiency, and 'whole of government' coordination to make the most effective use of scarce resources, local government is for the most part still treated as a junior subordinate by national authorities, rather than as a necessary and equal partner in the delivery of improved governance to citizens. Further analysis must be made of finance flows to and from central government, together with considerations of equity.

* Meanwhile, local government itself has paid little attention to the role of civil society, with a resulting disengagement between local leadership and the community, apart from those interests at local level - particularly in the business community - most affected by local government's regulatory or developmental decisions. 


\section{References}

Callinan, R (2007) 'Wrong Side of Paradise', Time, pp. 27-31.

Commonwealth Local Government Forum 2007, Commonwealth Local Government Handbook.

Commonwealth Local Government Forum (2005) 'Conference Report' of "Deepening Local Democracy" conference, Aberdeen 15-18 March 2005.

Commonwealth Secretariat (2005) Local Democracy and Good Governance in the Pacific: Report of the Regional Symposium (Suva, Fiji Islands) December 2004, Commonwealth Secretariat, London.

Cook Islands, Cook Islands Census 2006.

Fiji Islands Business, 'Urban Explosion: Gripping and choking our main urban centres', October 2007.

Fiji Local Government Association (2008) Executive Meeting address by $\mathrm{Mr}$ Vayeshnoi, January 31, 2008, <http://www.fiji.gov.fj/publish/page_11102.shtml> accessed 5th March 2008.

Filer, C (2004) 'Horses for Courses: Special Purpose authorities and local-level governance in Papua New Guinea', State Society and Governance in Melanesia, Discussion Paper 6.

Finin, G. A. 'Will Trust Funds Sustain the FSM and RMI? Lessons from the Tuvalu Model'.

Finin, G. A. (2002). 'Small is Viable: The Global Ebbs and Flows of a Pacific Atoll Nation', East-West Center Working Papers 15.

Gelu, A (2003) 'Legitimacy and Government - A Case Study: Papua New Ginea 1992 - Present', Governance in Pacific States Development Research Symposium, Suva, University of the South Pacific, Suva.

Ghai, Y (1990) 'Constitutional reviews in Papua New Guinea and Solomon Islands', The Contemporary Pacific 2: 313-333.

Government of Tonga, Statistics Dept (1997), 'Tonga population census, 1996', Nuku'alofa, Tonga

Graham, B (2005) Trust Funds in The Pacific: Their Role and Future, Asian Development Bank, Manila.

Harre, J. (ed) (1973) Living in Town: Problems and priorities in urban planning in the South Pacific, South Pacific Social Sciences Association \& School of Social and Economic Development, University of the South Pacific, Suva.

Jowitt, A (2007) 'Political Reviews: Melanesia in Review: Issues and Events, 2006 Vanuatu', The Contemporary Pacific 19(2): 605-612.

Khan, A (2007a) 'Local Government in Fiji', Fiji Local Government Association, Suva.

Khan, A (2007b) 'White Paper on Urban Development Policy for the Republic of Fiji Islands', Fiji Local Government Association, Suva.

Kiyagi-Nsubuga, J (ed) (2007) Local Democracy, Good Governance and Delivering the MDGs in Africa: Report of the Africa Regional Symposium, (Kampala, Uganda April 2006), , Commonwealth Local Government Forum, London.

Rawlings, G. E (1999) 'Foundations of Urbanisation: Port Vila Town and Pango village, Vanuatu', Oceania (70): 72-86. 
Reeves, P. \& T. T. Vakatora et al. (1996) The Fiji Islands. Towards A United Future. Report of the Fiji Constitution Review Commission, Parliament of Fiji, Suva.

Solomon Islands Household Income and Expenditure Survey, National Report, June 2005.

Spoehr, A., (ed). (1963) Pacific Port Towns and Cities: A Symposium, Bishop Museum Pres, Honolulu.

Storey, D (2005) 'Urban Governance in Pacific Island Countries: Advancing an Overdue Agenda', State Society and Governance in Melanesia, No.7.

Storey, D (2006) 'Urbanisation in the Pacific', State Society and Governance in Melanesia, AusAID Research Paper.

United Nations Capital Development Fund (2007) Delivering the Goods: Building Local Government Capacity to Achieve the Millennium Development Goals, United Nations Capital Development Fund, New York

White, G (2007) 'Indigenous Governance in Melanesia', State Society and Governance in Melanesia, No. 5.

Wolfers, E (1985), 'Decentralisation: Meaning, Forms, Objectives and Methods' in Decentralisation in the South Pacific: Local, Provincial and State Government in Twenty Countries. P. Larmour and R. Qalo, University of the South Pacific, Suva 1-23.

\section{Internet resources used in the research:}

Pacific Islands Legal Information Institute: http://www.paclii.org US Department of State: http://www.state.gov/misc/list/index.htm Fiji Local Government Association: http://www.fiji.gov.fj Fiji Population and Housing Census: http://www.statsfiji.gov.fj Millennium Development Goals in the Pacific www.mdgasiapacific.org United Nations Development Program - Fiji Multi-country office www.undp.org.fj United Nations Economic and Social Council for the Pacific www.unescap.org/huset/lgstudy/index.htm 